\title{
Prevalence and risk factors of Ascaris lumbricoides (Linnaeus, 1758), Trichuris trichiura (Linnaeus, 1771) and HBV infections in Southwestern China: a community-based cross sectional study
}

Peng-Lei Xiao 1,2,3, Yi-Biao Zhou ${ }^{1,2,3,6^{*}}$, Yue Chen ${ }^{4}$, Ya Yang ${ }^{1,2,3}$, Yan Shi ${ }^{1,2,3}$, Jian-Chuan Gao ${ }^{1,2,3}$, Wu-Li Yihuo ${ }^{5}$, Xiu-Xia Song ${ }^{1,2,3}$ and Qing-Wu Jiang ${ }^{1,2,3}$

\begin{abstract}
Background: Intestinal helminths do not cause severe diseases in general, however, when combined with other diseases such as immunodeficiency diseases, there would be massive complications. Infections with Hepatitis B Virus (HBV) may lead to immunological disturbances and defects of cellular immunity and there is a need of clarification whether HBV infections are associated with infections with intestinal helminths.

Methods: A community-based cross sectional study was conducted in Tezi town, Puge County of the Liangshan Prefecture, southwestern China from October 23rd to November 3rd, 2014. Four hundred and thirty eight people (median age $=37$ years, IQR $=22-49$ ) were enrolled in this study. Modified Kato-Katz thick smear was used to detect intestinal helminths. HBV DNA was quantified to confirm HBV infection.

Results: Among the 438 participants, $9.1 \%, 13.5 \%$ and $30.6 \%$ were infected with HBV, A. lumbricoides (L., 1758) and T. trichiura (L., 1771), respectively; $7.1 \%$ (30/438) were infected with both A. lumbricoides and T. trichiura and $2.3 \%$ (10/438) were co-infected with HBV and A. lumbricoides. The multivariate logistic regression analysis showed that age (21-30 years versus $>50$ years: $\mathrm{OR}=6.66,95 \% \mathrm{Cl}=2.15-20.68)$, drug abuse $(\mathrm{OR}=6.96,95 \% \mathrm{Cl}=1.11-$ 43.90), A. lumbricoides infection ( $\mathrm{OR}=3.60,95 \% \mathrm{Cl}=1.48-8.75)$, fertilization with faeces after disposal $(\mathrm{OR}=0.15$, $95 \% \mathrm{Cl}=0.04-0.47)$ and working on a farm $(\mathrm{OR}=4.59,95 \% \mathrm{Cl}=1.44-14.63)$ were significantly associated with HBV infection. Having toilets at home was negatively related to $A$. lumbricoides infection $(\mathrm{OR}=0.52,95 \% \mathrm{Cl}=0.27-0.98)$ and T. trichiura infection $(\mathrm{OR}=0.48,95 \% \mathrm{Cl}=0.28-0.80)$.
\end{abstract}

Conclusions: Ascaris lumbricoides was independently associated with HBV infection, and faeces might be the medium of HBV transmission. Improving hygiene conditions and habits are essential to reduce the risks of $A$. lumbricoides and T. trichiura infections.

Keywords: HBV, Ascaris lumbricoides, Trichuris trichiura, Faeces, Co-infection

\footnotetext{
*Correspondence: 1057339623@qq.com

${ }^{1}$ Fudan University School of Public Health, Building 8, 130 Dong An Road, Xuhui District, Shanghai 200032, China

${ }^{2}$ Key Laboratory of Public Health Safety, Fudan University, Ministry of

Education, Building 8, 130 Dong An Road, Xuhui District, Shanghai 200032,

China

Full list of author information is available at the end of the article
} 


\section{Background}

Intestinal helminths are common in developing countries including China especially in rural areas due to the poor economy and sanitation conditions. Globally, about two billion people are infected with at least one of the soil-transmitted helminth $(\mathrm{STH})$ species, particularly in developing countries with poor socioeconomic status [1]. Intestinal helminths do not cause severe diseases in general; however, when combined with other diseases like immunodeficiency diseases, there could be massive complications causing some serious consequences [2]. Some studies have reported that human immunodeficiency virus (HIV) increases the risk of helminthic infection [3] as HIV attacks the human immune system and causes cellular immunity dysfunction. For example, people infected with HIV were more likely to be infected with parasites, like Cryptosporidium, compared with those who were HIV negative [4]. Similarly, HBV infection could lead to immunological disturbances and defects of cellular immunity [5]. However, it needs to be clarified whether HBV infection is associated with helminth infections.

Ascaris lumbricoides and T. trichiura occur at high prevalence in rural areas of China [6]. At the same time, $\mathrm{HBV}$ infection is not uncommon in such places [7]. STH infections cause a loss of 39 million disability-adjusted life-years (DALYs), comparable to malaria or tuberculosis $[8,9]$. It is estimated that two billion people have either past or present infection with HBV in the world, and 240 million are chronic carriers of $\mathrm{HBV}$ surface antigen (HBsAg) [7]. In China, HBsAg carry rate was estimated to be $7.18 \%$ for people under 60 years of age in 2006 [10]. It has been indicated that HBV infection was associated with Schistosoma japonicum. The immunomodulation due to schistosome infections might restrict immune control of HBV leading to more severe viral infections [11]. So far few studies have investigated the relationship between HBV infection and intestinal helminths. In this study, we aimed to determine the prevalence and risk factors of infections with intestinal helminths including $A$. lumbricoides and $T$. trichiura and HBV infection in a rural community of southwestern China. We also tried to explore the association between HBV infection and $A$. lumbricoides and $T$. trichiura.

\section{Methods}

Study field

A community-based cross-sectional study was conducted in Tezi town $\left(27^{\circ} 36^{\prime} 39.43^{\prime \prime} \mathrm{N}, 102^{\circ} 40^{\prime} 38.31^{\prime \prime} \mathrm{E}\right.$; altitude: $2,147 \mathrm{~m}$ ), Puge County of the Liangshan Prefecture (Fig. 1), southwestern China from October 23rd to November 3rd, 2014. This town covers an area of $50.2 \mathrm{~km}^{2}$, with a population of approximately 4,000 inhabitants. Tezi is an underdeveloped region inhabited by the $\mathrm{Yi}$ people, an ethnic minority group in China. Lavatories, latrines or any other form of sanitation facilities were not available before 2006. Both human and domestic animal faeces were left untreated [12]. The current study included people aged 6 years or more, living in the area for more than 6 months every year. The participants had no severe organic or mental diseases and

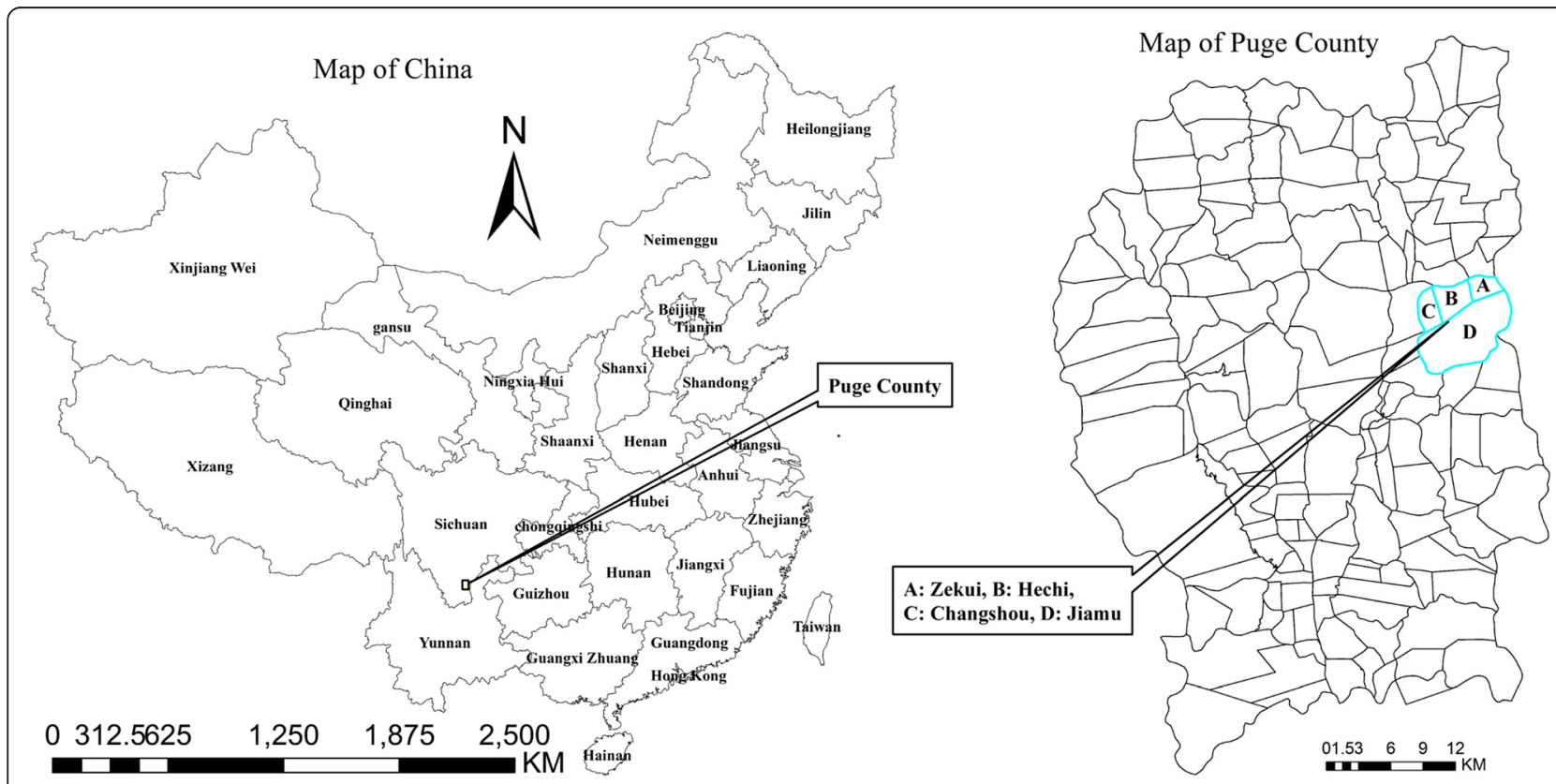

Fig. 1 Map of the study area, showing the Puge County and four villages. Villages 1-4 are labelled as A, B, C and D (Zekui, Hechi, Changshou and Jiamu, respectively) in the map of the Puge County 
pregnant women were excluded. A total of 645 individuals were randomly selected from the four villages (Zekui village, Hechi village, Jiamu village and Changshou village which were numbered as village 1-4 (see the map of Puge County in Fig. 1).

\section{Study procedures}

All the health workers participating in this investigation were staff of the local Center for Disease Control and Prevention (CDC) and were trained under the guidance of a unified protocol. Then health workers informed all the potential participants according to the protocol list and carefully explained the objectives, procedures and potential risks of the study.

All the residents sampled were screened for HBV surface antigen by using the Diagnostic Test Kit for HBV (colloidal gold) (product of Livzon Pharmaceutical Group Inc., Zhuhai, P. R. China, batch number: 2014080200, 100 persons per kit). Those with positive HBV surface antigen were asked to provide $5 \mathrm{ml}$ blood specimen for $\mathrm{HBV}$ DNA testing by using the diagnostic kit for quantification of HBV DNA (PCR-Fluorescence Probing) (product of Daan Gene Group Inc., Zhongshan, P. R. China, batch number: 2015002, 20 persons per kit).

The participants were given one faeces collection container and were asked to provide their faecal samples of at least $30 \mathrm{~g}$ collected in the morning at home. An oral description and specific instructions for handling and contamination avoidance of the stool samples were given to all the participants who gave consent. A questionnaire was administered and covered the information on sociodemographic factors, concomitant physical health, hygienic habits, farm work, drug abuse, and high-risk sex behaviours. All the samples were sent to the laboratory of the local CDC for examination as soon as possible after they were collected. The faecal samples were processed within $24 \mathrm{~h}$ post-collection by using the modified Kato-Katz thick smear (a semi-quantitative faeces examination technique) for detection of helminth eggs. Three smears of each faecal sample were prepared for examination. Every smear was initially read by two examiners and reviewed by a third examiner if there was disagreement.

\section{Statistical analysis}

Data were double-entered and crosschecked by using the EpiData software (version 3.1; The EpiData Association, Odense, Denmark). Descriptive summary measures of frequency and central tendency of participants' characteristics were computed. In the univariate analyses, the Pearson $x^{2}$ tests were used to examine the associations of participants' characteristics with HBV, A. lumbricoides or T. trichiura by computing crude odds ratios (ORs) with $95 \%$ confidence intervals (CIs). Logistic regression model was subsequently employed for multivariate analysis and adjusted ORs with $95 \%$ CIs were calculated for the risk factors identified. A two-sided P value of 0.05 or less was regarded as significant. Statistical analyses were carried out with the SPSS statistical package (version 17.0; IBM SPSS Institute, Inc., USA).

\section{Ethical statement}

This study was evaluated and approved by the Ethics Review Committee of the Ethical Institute of The School of Public Health, Fudan University. The potential participants who agreed to attend the study were asked to sign a written informed consent by the staff of the local CDC. If participants were less than 18 years of age, their parents were asked to sign a written parental permission. At the completion of the study and in accordance with the local treatment policies anti-helminthic treatment was offered for free to all participants found to be infected with intestinal helminths through the local CDC.

\section{Results}

There were 645 participants in the study. After the exclusion of participants whose faeces or blood samples were not collected or who did not complete the questionnaires, 438 participants were finally included in the analysis. Those excluded (median age $=32$ years, interquartile range (IQR) $=14-44$ ) were significantly younger $(P=0.003)$ than those included in the analysis (median age $=37$ years, IQR $=22-49$ ). There were no significant differences between them in gender, occupation, race, education and household income. Table 1 shows the characteristics of the participants. Among 438 participants, $39.3 \%$ were male, $96.8 \%$ were of Yi nationality, $65.3 \%$ were illiterate and $22.8 \%$ were unmarried. Infection rates of HBV, A. lumbricoides and T. trichiura were 9.1, 13.5 and $30.6 \%$ respectively. Of these, $7.1 \%(30 / 438)$ had a coinfection of $A$. lumbricoides and T. trichiura, $2.3 \%$ (10/438) had a co-infection of HBV and A. lumbricoides, and $2.7 \%$ (12/438) had a co-infection of $\mathrm{HBV}$ and $T$. trichiura (Table 2).

Table 3 shows the risk factors for HBV. Logistic regression analysis showed that age (21-30 years versus > 50 years: $\mathrm{OR}=6.66,95 \% \mathrm{CI}=2.15-20.68)$, drug abuse $(\mathrm{OR}=6.96,95 \% \mathrm{CI}=1.11-43.90)$, A. lumbricoides infection $(\mathrm{OR}=3.60,95 \% \mathrm{CI}=1.48-8.75)$, fertilization with faeces after disposal $(\mathrm{OR}=0.15,95 \% \mathrm{CI}=0.04-0.47)$ and work on farm $(\mathrm{OR}=4.59,95 \% \mathrm{CI}=1.44-14.63)$ were factors significantly associated with $\mathrm{HBV}$ infection.

Table 4 shows the risk factors for $A$. lumbricoides. Multivariate logistic regression analysis showed that village (village 1 versus village $4: \mathrm{OR}=3.14,95 \% \mathrm{CI}=1.35-$ 7.27), $\mathrm{HBV}$ infection ( $\mathrm{OR}=2.55,95 \% \mathrm{CI}=1.07-6.16)$ and infection with $T$. trichiura $(\mathrm{OR}=3.11$, $95 \% \mathrm{CI}=1.63-$ 5.93) were positively associated with $A$. lumbricoides infection. In addition, having toilets at home was negatively 
Table 1 Characteristics of the study population

\begin{tabular}{|c|c|c|c|}
\hline Variables/ states & & $\begin{array}{l}\text { No. } \\
\text { individuals }\end{array}$ & $\begin{array}{l}\text { Proportion } \\
\text { in \% }\end{array}$ \\
\hline \multirow[t]{6}{*}{ Age (years) } & $6-10$ & 54 & 12.3 \\
\hline & $11-20$ & 48 & 11.0 \\
\hline & $21-30$ & 66 & 15.1 \\
\hline & $31-40$ & 86 & 19.6 \\
\hline & $41-50$ & 88 & 20.1 \\
\hline & $>50$ & 96 & 21.9 \\
\hline \multirow[t]{2}{*}{ Gender } & Male & 172 & 39.3 \\
\hline & Female & 266 & 60.7 \\
\hline \multirow[t]{3}{*}{ Occupation } & Worker & 4 & 0.9 \\
\hline & Peasant & 370 & 84.5 \\
\hline & Else & 64 & 14.6 \\
\hline \multirow[t]{2}{*}{ Education } & Illiterate & 286 & 65.3 \\
\hline & $\begin{array}{l}\text { Elementary school } \\
\text { and above }\end{array}$ & 152 & 34.7 \\
\hline \multirow[t]{3}{*}{ Marital status } & Unmarried & 100 & 22.8 \\
\hline & First married & 293 & 66.9 \\
\hline & Divorced and other & 45 & 10.3 \\
\hline \multirow{5}{*}{$\begin{array}{l}\text { Home income } \\
\text { (¥yuan, RMB) }\end{array}$} & $<1,000$ & 12 & 2.7 \\
\hline & $1,000-2,999$ & 71 & 16.2 \\
\hline & $3,000-4,999$ & 142 & 32.4 \\
\hline & $5,000-9,999$ & 75 & 17.1 \\
\hline & $\geq 10,000$ & 138 & 31. \\
\hline \multirow[t]{2}{*}{ Drug abuse } & Yes & 9 & 2.1 \\
\hline & No & 429 & 97.9 \\
\hline \multirow[t]{2}{*}{ Work on farm } & Yes & 265 & 60.5 \\
\hline & No & 113 & 29.5 \\
\hline \multirow{2}{*}{$\begin{array}{l}\text { Clean food when } \\
\text { eaten raw }\end{array}$} & Always & 39 & 8.9 \\
\hline & Occasionally or never & 372 & 91.1 \\
\hline \multirow[t]{2}{*}{ Fertilization pattern } & Directly & 20 & 4.6 \\
\hline & After disposed & 374 & 95.4 \\
\hline \multirow[t]{2}{*}{ Raised animals } & Yes & 338 & 77.2 \\
\hline & No & 100 & 22.8 \\
\hline \multirow{2}{*}{$\begin{array}{l}\text { Wash hands before } \\
\text { meals }\end{array}$} & Always & 5 & 1.2 \\
\hline & Occasionally or never & 427 & 98.8 \\
\hline \multirow{2}{*}{$\begin{array}{l}\text { Source of drinking } \\
\text { water }\end{array}$} & Spring & 415 & 94.7 \\
\hline & Other & 23 & 5.3 \\
\hline \multirow[t]{2}{*}{ Toilets } & None & 188 & 42.9 \\
\hline & Yes & 250 & 57.1 \\
\hline Village No. & 1 & 114 & 26.0 \\
\hline
\end{tabular}

Table 1 Characteristics of the study population (Continued)

\begin{tabular}{llll}
\hline 2 & 115 & 26.3 \\
3 & 88 & 20.1 \\
4 & 121 & 27.6
\end{tabular}

RMB, Renminbi, the current rate of exchange be 9.66 yuan to 1 pound, i.e., $¥ 9.66$ yuan $(\mathrm{RMB})=£ 1 \mathrm{lb}(\mathrm{GBP})$

related to $A$. lumbricoides infection $(\mathrm{OR}=0.52,95 \% \mathrm{CI}=$ 0.27-0.98).

Table 4 shows the risk factors for $T$. trichiura. After adjustment in multivariate logistic regression analysis, village (village 2 versus village 4: $\mathrm{OR}=3.73,95 \% \mathrm{CI}=1.97-7.26$ ); village 3 versus 4 : $\mathrm{OR}=4.53,95 \% \mathrm{CI}=2.12-9.68), A$. lumbricoides infection $(\mathrm{OR}=3.09$, $95 \% \mathrm{CI}=1.62-$ $5.92)$ and age (11-20 years versus $>50$ years: $\mathrm{OR}=$ 3.72 , $95 \% \mathrm{CI}=1.59-8.67$ ) were significantly associated with $T$. trichiura infection. Having toilets at home was negatively associated with $T$. trichiura infection $(\mathrm{OR}=$ 0.48, $95 \% \mathrm{CI}=0.28-0.80$ ).

Stratification analysis by village showed that only gender (female versus male, $\mathrm{OR}=4.65,95 \% \mathrm{CI}=1.25-$ 17.27) and toilets (OR $=0.32,95 \% \mathrm{CI}=0.10-0.98)$ were related with $A$. lumbricoides in village 2 , and no risk factors associated with $A$. lumbricoides were found in other villages. However, different risk factors for $T$. trichiura were detected in different villages. Related risk factors of T. trichiura were not found in village 1 while toilets (having toilets was negatively related with $T$. trichiura, $\mathrm{OR}=0.25,95 \% \mathrm{CI}=0.11-0.54$ ), gender (female was negatively associated with $T$. trichiura versus male, $\mathrm{OR}=0.52$, $95 \% \mathrm{CI}=0.17-0.98$ ) and age (age ranges of $6-10$ years and 11-20 years were positively associated with $T$. trichiura compared with age above 50 years, $\mathrm{OR}=14.25$, $95 \% \mathrm{CI}=1.42-143.19$ and $\mathrm{OR}=14.25$, $95 \% \mathrm{CI}=2.07-$ 98.14) were found associated with $T$. trichiura in village 2 , village 3 and village 4 separately.

\section{Discussion}

This study reported the prevalence of HBV, A. lumbricoides and T. trichiura infections. The prevalence of $\mathrm{HBV}$ and $A$. lumbricoides infections were comparable to the national level while $T$. trichiura was higher than the national level $[10,13,14]$. Poor hygiene may be a major reason. Most people in this area drank unboiled water $(91.8 \%, 402 / 438)$ and ate raw food without washing (89.1\%, 366/411). Trichuris trichiura is mainly transmitted by contaminated water and food [15]. Furthermore, the altitude (1,800$2,500 \mathrm{~m})$ and temperature $\left(10-22{ }^{\circ} \mathrm{C}\right)$ were shown to be suitable for $T$. trichiura $[12,16]$.

Drug abuse and age were positively associated with HBV infection, which was consistent with the results previously reported $[17,18]$. Having toilets at home and villages were independently associated with $A$. lumbricoides 
Table 2 Infection rates of HBV, Ascaris lumbricoides and Trichuris trichiura

\begin{tabular}{llll}
\hline & No. of participants & No. of infected & Infection rate (\%) \\
\hline HBV & 438 & 40 & 9.1 \\
A. lumbricoides & 438 & 59 & 13.5 \\
T. trichiura & 438 & 134 & 30.6 \\
Co-infected with HBV and A. lumbricoides & 438 & 10 & 2.3 \\
Co-infected with HBV and T. trichiura & 438 & 12 & 2.7 \\
\hline
\end{tabular}

infection, and toilets, villages and age were independently associated with $T$. trichiura. Having toilets was the common protective factor for $A$. lumbricoides and $T$. trichiura. Previous studies in China showed that having toilets at home was associated with a lower risk of parasite infection [19]. Improvement of sanitation condition is essential to reduce the risk of $A$. lumbricoides and $T$. trichiura infections.

We noted that people had different risks of $A$. lumbricoides and T. trichiura infections in different villages. We therefore carried out a stratified analysis for A. lumbricoides and $T$. trichiura infections according to the villages and adjusted by all of their potential risk factors. We found different risk factors for helminthic infections in different villages. This might be the reason why people had different prevalences of $A$. lumbricoides and T. trichiura in different villages.

We found no significant differences between gender, occupation, race, education or household income and HBV, A. lumbricoides and T. trichiura. First of all, restricted to the study field, $96.8 \%$ of the study population were Yi people and therefore may restrict the statistical power to distinguish the meaning of race in this relationship. Besides, we selected people with the same criteria like aged 6 years or over, living in the area for more than 6 months every year. This means even though they had different occupations, education levels and home incomes, they had a similar way of life. So people included in this study might have similar characteristics in living, eating and drinking habits. They were exposed to the same culture and environmental surroundings, and were limited in the same resident scope. So the above might provide the explanation.

Some studies have reported that co-infection with HBV could accelerate the progression of schistosomiasis and make its treatment more complex and difficult, and vice versa [20, 21]. It might be expected that other helminths such as $A$. lumbricoides and $T$. trichiura might produce similar immunoreaction in humans. However, unlike S. japonicum, which can cause severe disease, $A$. lumbricoides or $T$. trichiura that inhabit the intestinal tract of humans are non-pathogenic parasites or only result in mild illnesses. Intestinal helminths most commonly cause diseases in immunocompromised individuals, such as people with $\mathrm{HBV}$, human immunodeficiency virus (HIV) infections and other severe diseases [22].

We found association between infections with HBV and $A$. lumbricoides. HBV might be a risk factor for $A$. lumbricoides infection, or infection with $A$. lumbricoides could increase the risk of $\mathrm{HBV}$ infection. HBV may cause an imbalance between Th1 and Th2 cells, and a study found that Th1 cells were suppressed while Th2 cells were enhanced [23]. Shift from Th1 to Th2 cells was also seen in parasite infections [24]. A balance of these two types of cells was important for the body's resistance to various pathogens. An interesting question to consider is whether immune responses for helminthic infection are facilitated by the replication of HBV DNA and if $\mathrm{HBV}$ infection contributes to a deterioration in helminthic infection. It is worthwhile further investigating how host immune response changes when co-infected with HBV and helminths.

We found that HBV infection was associated with fertilization pattern and farm work activities. Fertilization with faeces after disposal (i.e. faeces processed with fermentation, drying and other hazard-free treatments) was related to a lower prevalence of HBV infection compared with fertilization directly (i.e. no treatment of faeces before fertilisation) (8.3\% versus $30.0 \%$, OR $=0.21,95 \% \mathrm{CI}=$ 0.08-0.59). HBV DNA exists in faeces of people with HBV infection, i.e. faeces of these people were infectious for $\mathrm{HBV}$. This result is consistent with studies conducted by Guo et al. and Zhou et al. [25, 26]. The latter found that HBV DNA load was up to $2.245 \times 108$ copies $/ \mathrm{ml}$ in faeces, indicating that faeces could be the medium of HBV transmission. Thus it is understandable that working on a farm was related with HBV infection. People in this area were almost all barefoot while conducting farm work.

To prevent and control infections of $A$. lumbricoides and $T$. trichiura, the most effective measurement was to establish toilets or any other form of sanitation facilities drawn from our investigation. Strengthening health education for school children and taking preventive anthelmintic treatment are other effective ways. As to $\mathrm{HBV}$ infection, drug prohibition was the essential measurement and we found the key was implementing non-hazardous treatment of faeces and wearing shoes when working on farms 
Table 3 Results of the univariate and multivariate analyses for risk factors associated with HBV infection of the study population

\begin{tabular}{|c|c|c|c|c|c|}
\hline Variables/ states & & No. of participants & $\begin{array}{l}\text { No. of infections } \\
\text { (Rate in \%) }\end{array}$ & cOR (95 \% Cl) & aOR $(95 \% \mathrm{Cl})$ \\
\hline \multirow[t]{6}{*}{ Age (years) } & $6-10$ & 54 & $5(9.3)$ & $1.53(0.44,5.27)$ & $1.50(0.32,6.92)$ \\
\hline & $11-20$ & 48 & $2(4.2)$ & $0.65(0.13,3.36)$ & $1.01(0.18,5.69)$ \\
\hline & $21-30$ & 66 & $16(24.2)$ & $4.80(1.77,13.05)^{*}$ & $6.66(2.15,20.68)^{* *}$ \\
\hline & $31-40$ & 86 & $8(9.3)$ & $1.54(0.51,4.63)$ & $1.37(0.41,4.63)$ \\
\hline & $41-50$ & 88 & $3(3.4)$ & $0.53(0.13,2.18)$ & $0.55(0.12,2.52)$ \\
\hline & $>50$ & 96 & $6(6.3)$ & 1.00 & 1.00 \\
\hline \multirow[t]{2}{*}{ Gender } & Male & 172 & $14(8.1)$ & $0.82(0.41,1.62)$ & \\
\hline & Female & 266 & $26(9.8)$ & 1.00 & \\
\hline \multirow[t]{3}{*}{ Occupation } & Worker & 4 & $0(0)$ & 0 & \\
\hline & Peasant & 370 & $37(10.0)$ & $2.26(0.68,7.56)$ & \\
\hline & Else & 64 & $3(4.7)$ & 1.00 & \\
\hline \multirow[t]{2}{*}{ Education } & |lliterate & 286 & $25(8.7)$ & $0.88(0.45,1.71)$ & \\
\hline & $\begin{array}{l}\text { Elementary school } \\
\text { and above }\end{array}$ & 152 & $15(9.9)$ & 1.00 & \\
\hline \multirow[t]{3}{*}{ Marital status } & Unmarried & 100 & $8(8.0)$ & 1.00 & \\
\hline & First married & 293 & $28(9.6)$ & $1.22(0.54,2.76)$ & \\
\hline & Divorced and other & 45 & $4(8.9)$ & $1.12(0.32,3.94)$ & \\
\hline \multirow{5}{*}{$\begin{array}{l}\text { Home income } \\
\text { (¥ yuan, RMB) }\end{array}$} & $<1,000$ & 12 & $0(0)$ & 0 & \\
\hline & $1,000-2,999$ & 71 & $3(4.2)$ & $0.36(0.10,1.29)$ & \\
\hline & $3,000-4,999$ & 142 & $15(10.6)$ & $0.97(0.45,2.07)$ & \\
\hline & $5,000-9,999$ & 75 & $7(9.3)$ & $(0.33,2.17)$ & \\
\hline & $\geq 10,000$ & 138 & $15(10.9)$ & 1.00 & \\
\hline \multirow[t]{2}{*}{ Drug abuse } & Yes & 9 & $3(33.3)$ & $5.30(1.27,22.05)^{*}$ & $6.96(1.11,43.90)^{* *}$ \\
\hline & No & 429 & $37(8.6)$ & 1.00 & 1.00 \\
\hline \multirow[t]{2}{*}{ Work outside } & Yes & 134 & 17 & $1.78(0.92,3.45)$ & \\
\hline & No & 304 & 23 & 1.00 & \\
\hline \multirow[t]{2}{*}{ Work on farm } & Yes & 265 & $32(12.1)$ & $2.18(0.97,5.07)$ & $4.59(1.44,14.63)^{* *}$ \\
\hline & No & 113 & $5(4.4)$ & 1.00 & 1.00 \\
\hline \multirow[t]{3}{*}{ Clean food when eaten raw } & Always & 39 & $0(0)$ & 1.00 & \\
\hline & Occasionally & 244 & $28(11.5)$ & 0 & \\
\hline & Never & 128 & $9(7.0)$ & $1.71(0.78,3.75)$ & \\
\hline
\end{tabular}


Table 3 Results of the univariate and multivariate analyses for risk factors associated with HBV infection of the study population (Continued)

\begin{tabular}{|c|c|c|c|c|c|}
\hline \multirow[t]{2}{*}{ Fertilization pattern } & Directly & 20 & $6(30.0)$ & 1.00 & 1.00 \\
\hline & After disposal & 374 & $31(8.3)$ & $0.21(0.08,0.59)^{*}$ & $0.14(0.04,0.47)^{* *}$ \\
\hline \multirow[t]{2}{*}{ Raising Animals } & Yes & 338 & $34(10.1)$ & $1.75(0.71,4.30)$ & \\
\hline & No & 100 & $6(6.0)$ & 1.00 & \\
\hline \multirow[t]{2}{*}{ Toilets } & None & 188 & $19(10.1)$ & $0.852(0.43,1.57)$ & \\
\hline & Yes & 250 & $21(8.4)$ & 1.00 & \\
\hline \multirow[t]{4}{*}{ Village No. } & 1 & 114 & $16(14.0)$ & $1.81(0.79,4.18)$ & \\
\hline & 2 & 115 & $5(4.4)$ & $0.51(0.17,1.52)$ & \\
\hline & 3 & 88 & $9(10.2)$ & $1.27(0.49,3.26)$ & \\
\hline & 4 & 121 & $10(8.3)$ & 1.00 & \\
\hline \multirow[t]{2}{*}{ A. lumbricoides } & Negative & 379 & $30(7.9)$ & 1.00 & 1.00 \\
\hline & Positive & 59 & $10(17.0)$ & $2.37(1.09,5.16)^{*}$ & $3.60(1.48,8.75)^{* *}$ \\
\hline \multirow[t]{2}{*}{ T. trichiura } & Negative & 304 & $28(9.2)$ & 1.00 & \\
\hline & Positive & 134 & $12(9.0)$ & $0.97(0.48,1.97)$ & \\
\hline
\end{tabular}

$C I$ confidence interval, $O R$ odds ratio, $C O R$ crude odds ratio, $a O R$ adjusted odds ratio, $H B V$ hepatitis $B$ virus

$R M B$ Renminbi, the current rate of exchange be 9.66 yuan to 1 pound, i.e., $¥ 9.66$ yuan $(R M B)=£ 1 \mathrm{lb}$ (GBP)

${ }^{*}, P \leq 0.05$ in univariate analyses; ${ }^{*}, P \leq 0.05$ in and multivariate analyses 
Table 4 Results of the univariate and multivariate analyses for risk factors associated with Ascaris lumbricoides and Trichuris trichiura infections of the study population

\begin{tabular}{|c|c|c|c|c|c|c|c|c|}
\hline \multirow[b]{2}{*}{ Variables/ states } & & \multirow[b]{2}{*}{$\begin{array}{l}\text { No. of } \\
\text { participants }\end{array}$} & \multicolumn{3}{|l|}{ A. lumbricoides } & \multicolumn{3}{|l|}{ T. trichiura } \\
\hline & & & $\begin{array}{l}\text { No. of infections (Rate in } \\
\%)\end{array}$ & cOR $(95 \% \mathrm{Cl})$ & aOR $(95 \% \mathrm{Cl})$ & $\begin{array}{l}\text { No. of infections (Rate in } \\
\%)\end{array}$ & cOR $(95 \% \mathrm{Cl})$ & aOR $(95 \% \mathrm{Cl})$ \\
\hline \multirow[t]{6}{*}{ Age (years) } & $6-10$ & 54 & $7(13.0)$ & $1.04(0.38,2.83)$ & & $22(40.7)$ & $\begin{array}{l}1.95(0.96 \\
3.97)^{*}\end{array}$ & $1.69(0.73,3.93)$ \\
\hline & $11-20$ & 48 & $7(14.6)$ & $1.20(0.44,3.26)$ & & $21(43.8)$ & $\begin{array}{l}2.21(1.06 \\
4.58)^{*}\end{array}$ & $\begin{array}{l}3.72(1.59 \\
8.67)^{* *}\end{array}$ \\
\hline & $21-30$ & 66 & $7(10.6)$ & $0.83(0.31,2.34)$ & & $17(25.8)$ & $0.99(0.48,2.02)$ & $1.24(0.54,2.82)$ \\
\hline & $31-40$ & 86 & $13(15.1)$ & $1.25(0.54,2.90)$ & & $28(32.6)$ & $1.37(0.72,2.60)$ & $1.61(0.77,3.36)$ \\
\hline & $41-50$ & 88 & $13(14.8)$ & $1.21(0.52,2.82)$ & & $21(23.9)$ & $0.89(0.46,1.74)$ & $1.01(0.47,2.18)$ \\
\hline & $>50$ & 96 & $12(12.5)$ & 1.00 & & $25(26.0)$ & 1.00 & 1.00 \\
\hline \multirow[t]{2}{*}{ Gender } & Male & 172 & $23(13.4)$ & $0.99(0.56,1.73)$ & & $55(32.0)$ & $1.13(0.74,1.68)$ & \\
\hline & Female & 266 & $36(13.5)$ & 1.00 & & $79(29.7)$ & 1.00 & \\
\hline \multirow[t]{2}{*}{ Wash hands before meals } & Always & 5 & $0(0)$ & 0.00 & & $1(20.0)$ & $0.60(0.06,5.05)$ & \\
\hline & $\begin{array}{l}\text { Occasionally or } \\
\text { never }\end{array}$ & 427 & $59(13.8)$ & 1.00 & & $132(30.9)$ & 1.00 & \\
\hline \multirow[t]{2}{*}{ Source of drinking water } & Spring & 415 & $57(13.7)$ & $1.21(0.35,4.15)$ & & 131 (31.6) & $1.50(0.59,3.83)$ & \\
\hline & Other & 23 & $2(8.7)$ & 1.00 & & $3(13.0)$ & 1.00 & \\
\hline \multirow[t]{2}{*}{ Work on farm } & Yes & 305 & $40(13.1)$ & $0.91(0.50,1.63)$ & & $90(29.5)$ & $0.85(0.50,1.31)$ & \\
\hline & No & 133 & $19(14.3)$ & 1.00 & & $44(33.1)$ & 1.00 & \\
\hline \multirow{3}{*}{$\begin{array}{l}\text { Clean food when eaten } \\
\text { raw }\end{array}$} & Always & 39 & $8(20.5)$ & $2.10(0.81,5.46)$ & & $16(41.0)$ & $1.53(0.73,3.21)$ & \\
\hline & Occasionally & 244 & $33(13.5)$ & $1.27(0.60,2.48)$ & & $72(29.5)$ & $0.92(0.58,1.46)$ & \\
\hline & Never & 128 & $14(10.9)$ & 1.00 & & $40(31.3)$ & 1.00 & \\
\hline \multirow[t]{2}{*}{ Fertilization pattern } & Directly & 20 & $5(25.0)$ & 1.00 & & $6(30.0)$ & 1.00 & \\
\hline & After disposal & 374 & $49(13.1)$ & $0.45(0.16,1.30)$ & & $112(30.0)$ & $1.00(0.37,2.66)$ & \\
\hline \multirow[t]{2}{*}{ Animal raise } & Yes & 338 & $48(14.2)$ & $1.34(0.67,2.69)$ & & $106(31.4)$ & $1.18(0.72,1.92)$ & \\
\hline & No & 100 & $11(11.0)$ & 1.00 & & $28(28.0)$ & 1.00 & \\
\hline \multirow[t]{2}{*}{ Toilets } & None & 188 & 35 (18.6) & 1.00 & 1.00 & $69(36.7)$ & 1.00 & 1.00 \\
\hline & Yes & 250 & $24(9.6)$ & $\begin{array}{l}0.46(0.27 \\
0.81)^{*}\end{array}$ & $\begin{array}{l}0.51(0.27 \\
0.98)^{* *}\end{array}$ & $65(26.0)$ & $\begin{array}{l}0.61(0.40 \\
0.91)^{*}\end{array}$ & $\begin{array}{l}0.48(0.28 \\
0.80)^{* *}\end{array}$ \\
\hline \multirow[t]{2}{*}{ Village No. } & 1 & 114 & $25(21.9)$ & $\begin{array}{l}3.12(1.42 \\
6.83)^{*}\end{array}$ & $\begin{array}{l}3.14(1.35 \\
7.27)^{* *}\end{array}$ & $29(25.4)$ & $1.63(0.86,3.06)$ & $1.34(0.64,2.79)$ \\
\hline & 2 & 115 & 19 (16.3) & $\begin{array}{l}2.20(0.97 \\
4.95)^{*}\end{array}$ & $1.61(0.67,3.89)$ & $48(41.7)$ & $\begin{array}{l}3.41(1.87 \\
6.21)^{*}\end{array}$ & $\begin{array}{l}3.73(1.92 \\
7.26)^{* *}\end{array}$ \\
\hline
\end{tabular}


Table 4 Results of the univariate and multivariate analyses for risk factors associated with Ascaris lumbricoides and Trichuris trichiura infections of the study population (Continued)

\begin{tabular}{|c|c|c|c|c|c|c|c|c|}
\hline & 3 & 88 & $5(5.7)$ & $0.67(0.22,2.03)$ & $0.71(0.21,2.36)$ & $36(40.9)$ & $\begin{array}{l}3.30(1.75 \\
6.22)^{*}\end{array}$ & $\begin{array}{l}4.53(2.12 \\
9.68)^{* *}\end{array}$ \\
\hline & 4 & 121 & $10(8.3)$ & 1.00 & 1.00 & $21(17.4)$ & 1.00 & 1.00 \\
\hline \multirow[t]{2}{*}{ HBV } & Negative & 398 & $49(12.3)$ & 1.00 & 1.00 & $122(30.7)$ & 1.00 & \\
\hline & Positive & 40 & $10(25.0)$ & $\begin{array}{l}2.37(1.89 \\
5.16)^{*}\end{array}$ & $\begin{array}{l}2.55(1.07 \\
6.06)^{* *}\end{array}$ & $12(30.0)$ & $0.97(0.48,1.97)$ & \\
\hline \multirow[t]{2}{*}{ A. lumbricoides } & Negative & 379 & & & & $103(27.2)$ & 1.00 & 1.00 \\
\hline & Positive & 59 & & & & $31(52.5)$ & $\begin{array}{l}2.97(1.70 \\
5.19)^{*}\end{array}$ & $\begin{array}{l}3.09(1.62 \\
5.92)^{* *}\end{array}$ \\
\hline \multirow[t]{2}{*}{ T. trichiura } & Negative & 304 & $28(9.2)$ & 1.00 & 1.00 & & & \\
\hline & Positive & 134 & $31(23.1)$ & $\begin{array}{l}2.97(1.70 \\
5.19)^{*}\end{array}$ & $\begin{array}{l}3.11(1.63 \\
5.93)^{* *}\end{array}$ & & & \\
\hline
\end{tabular}

$C$ confidence interval, $O R$ odds ratio, $C O R$ crude odds ratio, $a O R$ adjusted odds ratio, $H B V$ hepatitis $B$ virus

${ }^{*}, P \leq 0.05$ in univariate analyses; ${ }^{* *}, P \leq 0.05$ in and multivariate analyses 
in this area. They were also protective for people against helminthic infections.

There were several limitations for the study. The excluded participants were generally younger than those included in this study because a larger number of young people left for cities to find jobs. Potential biases might result in an underestimation of the prevalence of HBV infection as young adults were at higher risk for HBV infection [27]. Some information was lacking including the length of time spent working on a farm. We could not establish a dose-response relationship between this and HBV infection. Because of the nature of crosssectional design, we were not able to give the affirmative conclusion for the relationship between HBV infection and $A$. lumbricoides. The sample size was not enough for performing more detailed stratified statistical analysis by villages. In view of these limitations, the findings should be interpreted with caution. We did not find a significant association between $\mathrm{HBV}$ infection and $T$. trichiura, which should have a similar to A. lumbricoides transmission route and pathogenicity.

\section{Conclusions}

In conclusion, drug abuse, age of 21-30 years and infections with $A$. lumbricoides were independently associated with HBV infection. Having toilets was independently associated with a reduced risk of $A$. lumbricoides and $T$. trichiura infections. Working on a farm and fertilization with faeces without disposal were positively associated with HBV infection. Improving hygiene conditions and habits, particularly having toilets at home, are essential for reducing the risks of $A$. lumbricoides and T. trichiura infections.

\section{Abbreviations}

Cl: confidence interval; DALYs: disability-adjusted life years;

DNA: deoxyribonucleic acid; HBV: Hepatitis B Virus; HIV: human immunodeficiency virus; OR: odds ratio; STH: soil-transmitted helminth.

\section{Competing interests}

The authors have declared that they have no competing interests.

\section{Authors' contributions}

P-LX participated in the data collection, statistical analysis and interpretation of the data and the preparation of the manuscript. Y-BZ, YC and Q-WJ participated in the interpretation of the data and in the critical review and revision of the manuscript draft. X-XS, YY, YS and J-CG performed data collection for the study and participated in the preparation of the manuscript. YY and W-IY were responsible for data management and read all the smears. All authors read and approved the final manuscript.

\section{Acknowledgements}

We would like to thank the staff of the Center for Diseases Control in Puge County for their efforts in assisting with the collection and identification of data. We are grateful to the local State government for supporting this study in the area.

\section{Author details}

${ }^{1}$ Fudan University School of Public Health, Building 8, 130 Dong An Road, Xuhui District, Shanghai 200032, China. ${ }^{2}$ Key Laboratory of Public Health Safety, Fudan University, Ministry of Education, Building 8, 130 Dong An
Road, Xuhui District, Shanghai 200032, China. ${ }^{3}$ Fudan University Center for Tropical Disease Research, Building 8, 130 Dong An Road, Xuhui District, Shanghai 200032, China. ${ }^{4}$ School of Epidemiology, Public Health and Preventive Medicine, Faculty of Medicine, University of Ottawa, 451 Smyth Road, Ottawa, Ontario K1H 8M5, Canada. ${ }^{5}$ Puge Center for Disease Prevention and Control, 4 Qing Nian Road, Puge County, Liangshan Prefecture, Sichuan Province 615399, China. ${ }^{6}$ Department of Epidemiology, School of Public Health, Fudan University, Room 307, Building 8, 130 Dong An Road, Xuhui District, Shanghai 200032, China.

Received: 1 October 2015 Accepted: 19 December 2015

Published online: 24 December 2015

\section{References}

1. Hotez PJ, Kamath A. Neglected tropical diseases in sub-Saharan Africa: review of their prevalence, distribution, and disease burden. Plos Neglect Trop D. 2009;3:e412.

2. Tian L, Wang T, Lv S, Wang F, Guo J, Yin X, et al. HIV and intestinal parasite co-infections among a Chinese population: an immunological profile. Infect Dis Poverty. 2013;2:18.

3. Gomez Morales MA, Pozio E, Croppo GP. Serodiagnosis of cryptosporidiosis in Italian HIV-positive patients by means of an oocyst soluble antigen in an ELISA. J Infect. 1992;25:229-36.

4. Kurniawan A, Dwintasari W, Connelly L, Nichols RAB, Yunihastuti E, Karyadi T, et al. Cryptosporidium species from human immunodeficiency-infected patients with chronic diarrhea in Jakarta, Indonesia. Ann Epidemiol. 2013;23:720-3.

5. Ferrari C. HBV and the immune response. Liver Int. 2015;35(Suppl 1):121-8.

6. Wang $S Y$, Yin $Q$, Wang BH, Wang $X$. A survey on current status of the important parasitic diseases in human population of China. China and Foreign Med Treat. 2013;32(27):143.

7. Ott JJ, Stevens GA, Groeger J, Wiersma ST. Global epidemiology of hepatitis $B$ virus infection: New estimates of age-specific HBsAg seroprevalence and endemicity. Vaccine. 2012;30:2212-9.

8. WHO Expert Committee. Prevention and control of schistosomiasis and soil-transmitted helminthiasis. World Health Organ Tech Rep Ser. 2002; 912:1-57.

9. Pullan RL, Brooker SJ. The global limits and population at risk of soiltransmitted helminth infections in 2010. Parasit Vectors. 2012:5:81.

10. Cui FQ. Survey on serological epidemiology on hepatitis B in China. Zhongguo Yi Miao He Mian Yi. 2010;16(4):341-53.

11. Chen L, Liu W, Lei J, Guan F, Li M, Song W, et al. Chronic Schistosoma japonicum infection reduces immune response to vaccine against Hepatitis $B$ in mice. PLoS One. 2012;7:e51512.

12. Yi Huo WL, Zhou YB, Liu GM, Wu ZS, Wang SA, Xu L, et al. Effect of fouryear comprehensive schistosomiasis control in Puge County, Sichuan Province. Zhongguo Xue Xi Chong Bing Fang Zhi Za Zhi. 2009;21:276-9.

13. Sun $F H$, Shen $M X, X u X Z, C A o H J$, Jiang $W C$, Ji $Z H$, et al. Investigation on human ascaris infection in China. Zhongguo bing yuan sheng wu xue za zhi. 2008:3(12):936-9.

14. Wang SH, Chen ZY, Tang LN, Li AM, Xu LN. Current situation and influencing factors of Trichuris trichiura in China. Zhongguo bing yuan sheng wu xue za zhi. 2008;3(12):929-32.

15. Li YM, Huang Y, Yin KX, Sheng ZD. Influence factor analysis of intestinal parasite infection in population. Zhonghua Yu Fang Yi Xue Za Zhi. 2001; 2(4):310-1.

16. Yang $J$, Yang $H M$, Wang $Y K$, Zhang $L L$, Yu H, Zhang BX, et al. A survey of epidemiological factors in Hookworm, Ascaris and Trichuris infections. Zhongguo Ji Sheng Chong Xue Yu Ji Sheng Chong Bing Za Zhi. 1994;155 Suppl 1:157.

17. Min JA, Yoon Y, Lee HJ, Choi J, Kwon M, Kim K, et al. Prevalence and associated clinical characteristics of hepatitis B, C, and HIV infections among injecting drug users in Korea. J Med Virol. 2013;85:575-82.

18. Yun H, Kim D, Kim S, Kang S, Jeong S, Cheon Y, et al. High prevalence of $\mathrm{HBV}$ and HCV infection among intravenous drug users in Korea. J Med Virol. 2008;80:1570-5.

19. Wang GF, Chen YD, Zhou CH, Chu TJ. Analysis of influencing factors of Trichuris trichiura infection in demonstration plots of comprehensive control of parasitic diseases. Zhongquo xue xi chong bing fang zhi za zhi. 2011;23(5):495-500. 
20. Jia ZW, Chu DY, Wang W, Luo QL, Shen JL. Effects of HBV infection on hepatic fibrosis and level of Th1/Th2 cytokines in the patients with schistosomiasis japonica. Zhonghua Jian Yan Yi Xue Za Zhi. 2007;30:1105-8.

21. Du H. Relationship between advanced schistosomiasis and HBV infection. Zhongguo xue xi chong bing fang zhi za zhi. 2013;25(1):115-7.

22. Grencis RK. Immunity to helminths: resistance, regulation, and susceptibility to gastrointestinal nematodes. Annu Rev Immunol. 2015;33:201-25.

23. Hultgren C, Milich DR, Weiland O, Sallberg M. The antiviral compound ribavirin modulates the $T$ helper (Th) 1/Th2 subset balance in hepatitis $B$ and C virus-specific immune responses. J Gen Virol. 1998;79(Pt 10):2381-91.

24. Moreau $\mathrm{E}$, Chauvin A. Immunity against helminths: interactions with the host and the intercurrent infections. J Biomed Biotechnol. 2010;2010:428593.

25. Guo R, Chen Z, Chen N, Chen Y. Quantitative real-time PCR analysis of intestinal regular fungal species in fecal samples from patients with chronic hepatitis B virus infection. Lab Med. 2010:41:591-6.

26. Zhou XT, Lv R, Zheng JS, Chen GS, Liu YY, Ye Y, et al. Study on relationship among hepatitis $B$ virus markers and content of HBV-DNA in feces of patients with hepatitis B virus infection. Acta Universitatis Medicinalis Anhui. 2014:10:1510-3.

27. Khan F, Shams S, Qureshi ID, Israr M, Khan H, Sarwar MT, et al. Hepatitis B virus infection among different sex and age groups in Pakistani Punjab. Virol J. 2011:8:225.

\section{Submit your next manuscript to BioMed Central} and we will help you at every step:

- We accept pre-submission inquiries

- Our selector tool helps you to find the most relevant journal

- We provide round the clock customer support

- Convenient online submission

- Thorough peer review

- Inclusion in PubMed and all major indexing services

- Maximum visibility for your research

Submit your manuscript at www.biomedcentral.com/submit 